\title{
Development of Science Literacy Instruments in the Direct Current
}

\author{
Dony Susandi ${ }^{1}$, ED Jannati ${ }^{2}$, A Rachmat $^{3}$, I Kaniawati ${ }^{4}$, P Siahaan $^{5}$ \\ \{dys@unma.ac.id ${ }^{1}$,eidelweis_unma@yahoo.com ${ }^{2}$, asep18rachmat75@gmail.com ${ }^{3}$ \} \\ Industrial Engineering, Majalengka University, Majalengka, Indonesia ${ }^{1}$, Mechanical Engineering, \\ Majalengka University, Majalengka, Indonesia ${ }^{2,3}$
}

\begin{abstract}
This research aims to develop scientific literacy instruments in the direct current series chapter. The measured aspects of scientific literacy are aspects of content knowledge, procedural knowledge, and scientific attitudes. The research method was conducted with a qualitative and empirical analysis approach. The empirical analysis is used to measure the feasibility of the instrument in the form of validation, reliability, differentiation test and convenience test. The sample used to measure the feasibility of research results is the second-semester Informatics Engineering student at Majalengka University. The results of expert studies on the item show that it is appropriate, as well as the results of empirical tests showing that the scientific literacy instrument developed in the direct current electricity chapter is feasible to be applied in learning.
\end{abstract}

Keywords: Instrument Development, Scientific Literacy, Direct Current Electricity

\section{Introduction}

Student achievement in science is assessed by two international surveys, namely Trends in International Mathematics and Science Studies (TIMSS) and the Program for International Student Assessment (PISA) [1]

Indonesia, in part, by some PISA exam materials that are not included in the Indonesian curriculum, but also by the unavailability of textbooks that meet the curriculum requirements and standard competencies for testing(Kemendikbud). Results of research at the Faculty of Engineering, Majalengka University, researchers found that students' scientific literacy skills are still low[2].

Therefore we need a good test of scientific literacy so that it can be applied in learning. This is an effort to improve the scientific literacy of Indonesian students.

\section{Methods}

\subsection{Sample}

The population of this study was all class XI in one vocational high school in Majalengka City in the 2019-2010 school year. Because the population is too much, the research sample is one class of automotive majors class XI, amounting to 30 students with cluster random sampling 
techniques, when the total area of the research is too large a better way for the researcher is to divide the area into smaller part of the same or equal and then select randomly from the smaller units. It is expected that the total population is to be divided into relatively smaller numbers which are still from the clusters of smaller units and then some of these cluster units will be selected randomly so that it will be included in the general sampling [3].

\subsection{Instruments}

The research instrument used was a matter of scientific literacy according to PISA 2015 (annex). Measured aspects of scientific literacy are aspects of content knowledge, procedural knowledge, and scientific attitudes, multiple-choice test questions in the direct current electricity chapter. The research method is qualitative and empirical. Qualitative analysis, the matter of scientific literacy is validated by two content experts. After testing the questions, the researchers then analyze empirically used to measure the feasibility of the instrument in the form of validation, reliability, ease analysis and distinctive analysis [4].

\section{Result and Discussion}

The results of the analysis of the test problems as Table 1 shown:

Table 1. Table of validity, difficulty level, and distinguishing test.

\begin{tabular}{|c|c|c|c|c|c|c|c|}
\hline \multirow{2}{*}{$\begin{array}{c}\text { Test } \\
\text { Num } \\
\text { ber }\end{array}$} & \multirow{2}{*}{$\begin{array}{l}\text { Validity } \\
\text { rpbis }\end{array}$} & \multirow{2}{*}{ Interpretation } & \multicolumn{2}{|c|}{ Difficulty level } & \multicolumn{2}{|c|}{ Distinguishing test } & \multirow{2}{*}{ Information } \\
\hline & & & Nilai & Interpretation & Nilai & Interpretation & \\
\hline 1 & 0.47 & Valid & 0.44 & medium & 0.48 & good & accepted \\
\hline 2 & 0.59 & Valid & 0.70 & easy & 0.23 & enough & revised \\
\hline 3 & 0.62 & Valid & 0.15 & hard & 0.26 & enough & revised \\
\hline 4 & 0.59 & Valid & 0.19 & hard & 0.09 & poor & replaced \\
\hline 5 & 0.51 & Valid & 0.70 & easy & 0.42 & good & accepted \\
\hline 6 & 0.46 & Valid & 0.59 & medium & 0.64 & good & accepted \\
\hline 7 & 0.54 & Valid & 0.15 & hard & 0.31 & good & accepted \\
\hline 8 & 0.60 & Valid & 0.56 & medium & 0.41 & good & accepted \\
\hline 9 & 0.57 & Valid & 0.15 & hard & 0.21 & enough & revised \\
\hline 10 & 0.61 & Tidak & 0.11 & hard & 0.08 & poor & replaced \\
\hline 11 & 0.00 & Valid & 0.00 & hard & 0.00 & poor & replaced \\
\hline 12 & 0.59 & Valid & 0.07 & hard & 0.01 & poor & replaced \\
\hline 13 & 0.50 & Valid & 0.41 & medium & 0.70 & excellent & accepted \\
\hline
\end{tabular}

The following Table 2 is an aspect of scientific literacy skills in each issue number 
Table 2. Aspect of scientific literacy skills.

\begin{tabular}{cllc}
\hline No & \multicolumn{1}{c}{ Aspek Literasi sains } & \multicolumn{1}{c}{ Nomor soal } & Jumlah \\
\hline 1 & content knowledge & $1,2,3,4$ & 4 \\
2 & procedural knowledge & $5,6,7,8,9$ & 5 \\
3 & scientific attitudes & $10,11,12,13$ & 4 \\
\hline
\end{tabular}

From Table 1 we can see that for question number 11, no one answered correctly. this is because students are fooled by multiple-choice options. The problem is: "From the article above electricity is very dangerous, how is it safe to check the electrical outlet? Namely checking one by one using a screwdriver by putting ... "and the answer choices are: (a) Back of hand, wear shoes and step on the floor; (b) Back of hand, wear shoes and not step on the floor; (c) palms, wearing shoes and stepping on the floor; (d) palms, wearing shoes and not stepping on the floor; (e) Palm the hand, not wearing shoes and stepping on the floor. The correct answer is option b, with the back of the hand because it is feared there is an electric shock, then the hand will reply away, by wearing shoes because of the insulator, not stepping on the floor feared of electricity propagating on the floor. Because none of the students answered, we will replace question number 11.

And the results of the reliability showed 0.58 indicating that the question was feasible to be applied in learning.

\section{Conclusion}

The scientific literacy test instrument that we tested in class XI Vocational students is one of the schools in the city of Majalengka, the results are worth applying to learn. This scientific literacy instrument prepared for the 2015 PISA type includes aspects of content knowledge, procedural knowledge, and attitude aspects. we developed the test instrument in the direct current circuit chapter.

Acknowledgments. The researchers would like to thank RISTEK DIKTI, for providing research grant funds, so that this research went smoothly.

\section{References}

[1] Parlindungan, S., Kaniawati, I., \& Setiawan, A.: Improving Secondary School Students' Scientific Literacy Ability Through The Design Of Better Science Textbooks. Journal of Turkish Science Education. Vol. 14, pp. 92-107 (2017)

[2] Jannati, E. D., Setiawan, A., Siahaan, P. and Rochman C.: Virtual laboratory learning media development to improve science literacy skills of mechanical engineering students on basic physics concept of material measurement IOP Conf. Series: Journal of Physics: Conf. Series 1013 (2018)

[3] Etikan, I., and Bala, K.: Sampling and sampling methods. Biom Biostat Int J 5(6): 00149. (2017)

OECD: $\quad$ PISA 2015 draft science framework march 2013. https://www.oecd.org/pisa/pisaproducts/Draft\%20PISA\%202015\%20Science\%20Framework\%20.pdf .(2015)

[4] Arikunto dan Cepi, S. A. J.: Educational Program Evaluation. Jakarta : Bumi Aksara.(2009) 
[5] McKinnon, J.: Reliability and Validity in Field Research: Some Strategies and Tactics. Accounting, Auditing \& Accountability Journal, Vol. 1 No. 1, pp. 34-54 (1988) 